\title{
Fate of peptides in peptidase mutants of Lactococcus lactis
}

\author{
Edmund R. S. Kunji, ${ }^{2 \dagger}$ Igor Mierau, ${ }^{1 \dagger}$ Bert Poolman, ${ }^{2}$ \\ Wil N. Konings, ${ }^{2}$ Gerard Venema ${ }^{1 *}$ and Jan Kok ${ }^{1}$ \\ Department of ${ }^{1}$ Genetics and ${ }^{2}$ Microbiology, Groningen \\ Biomolecular Sciences and Biotechnology Institute, \\ Kerklaan 30, 9751 NN Haren, The Netherlands.
}

\section{Summary}

The utilization of exogenous peptides was studied in mutants of Lactococcus lactis in which combinations of the peptidase genes pepN, pepC, pepO, pepX and pepT were deleted. Multiple mutants lacking PepN, PepC, PepT plus PepX could not grow on peptides such as Leu-Gly-Gly, Gly-Phe-Leu, Leu-Gly-Pro, Ala-Pro-Leu and Gly-Leu-Gly-Leu, respectively, indicating that no other peptidases are present to release the essential amino acid Leu. In these mutants, peptides accumulate intracellularly, demonstrating that peptides are translocated as whole entities prior to degradation. The mutant lacking all five peptidases could still grow on Gly-Leu and Tyr-Gly-Gly-PheLeu, which confirmed the presence of a dipeptidase and led to the identification of an unknown PepOlike endopeptidase. These studies have also shown that the general aminopeptidases PepN, PepC and PepT have overlapping but not identical specificities and differ in their overall activity towards individual peptides. In contrast, PepX has an unique specificity, because it is the only enzyme which can efficiently degrade Ala-Pro-Leu. The concerted action of peptidases in the breakdown of particular peptides revealed how these substrates are utilized as sources of nitrogen.

\section{Introduction}

The proteolytic system of Lactococcus lactis exemplifies a pathway present in several bacteria which utilize exogenous proteins and peptides as the nitrogen source. This pathway differs from the proteolytic system that is used by bacteria for endogenous protein turnover. One of the unique components is an extracellular proteinase (PrtP) that hydrolyses milk proteins to oligopeptides ranging from 4-30 amino acid residues in length (Juillard et al., 1995).

Received 18 December, 1995; revised 23 March, 1996; accepted 11 April, 1996. †These authors contributed equally to this work. *For correspondence. Tel. (50) 3632092; Fax (50) 3632348.
For transport of peptides, three translocators have been identified which differ from those of enteric bacteria (Payne and Smith, 1994): (i) a proton-motive-force-driven di/ tripeptide transporter for relatively hydrophilic peptides (DtpT); (ii) an ATP-driven di/tripeptide permease (DtpP) for more-hydrophobic peptides; and (iii) an ATP-driven oligopeptide transport system (Opp) for peptides of four up to at least eight amino acid residues (Kunji et al., 1996). The latter system is responsible for transport of the majority of peptides formed by PrtP (Kunji et al., 1995). For degradation of peptides, a multitude of peptidases is present intracellularly (for references see Kunji et al., 1996). To date, these peptidases have been characterized with respect to their ability to degrade selected peptides in vitro. The general aminopeptidases $\mathrm{PepN}$ and $\mathrm{PepC}$ are able to release $\mathrm{N}$-terminal amino acid residues from a wide range of di-, tri- and oligopeptides. The aminopeptidases PepV and PepT also have broad specificities, but are specific for di- and tripeptides, respectively. The endopeptidases PepO, PepF and PepF2 hydrolyse internal peptide bonds of oligopeptides. More-specific sequences are recognized and cleaved by PepA (Glu/Asp $\left.\downarrow(X)_{n}\right)$, PepR (Pro $\downarrow X)$, Pepl (Pro $\left.\downarrow(X)_{n}\right)$, PepQ (X $\downarrow$ Pro), PepP $\left(\mathrm{X} \downarrow \operatorname{Pro}-(\mathrm{X})_{\mathrm{n}}\right)$ and PepX (X-Pro $\left.\downarrow(X)_{n}\right)$ (cleavage sites are indicated by arrows; Kunji et al., 1996). Although kinetic parameters for different substrates have been determined, the data are insufficient to describe the role of these peptidases in the degradation of peptides in vivo.

Peptide degradation in vivo has been examined in some depth in Escherichia coli and Salmonella typhimurium, where the involvement of peptidases was studied in peptide catabolism and protein turnover (Miller and Mackinnon, 1974; Miller and Schwartz, 1978; Yen et al., 1980a,b; Miller and Green, 1983). To study the contribution of individual peptidases in the utilization of proteins and peptides as the source of nitrogen in L. lactis, single and multiple mutants were constructed which lacked combinations of the following five peptidase genes: pepO, pepN, pepC, pepT and pepX (Mierau et al., 1996). Inactivation of ever more peptidases caused increasingly lower growth rates of the mutants in milk and it was demonstrated that the observed growth defects were related to a decreased ability to degrade casein-derived peptides into free amino acids needed for growth. However, the complexity of the peptide mixture generated from caseins by the action of PrtP does not allow accurate evaluation of the role of individual peptidases in the proteolytic pathway. 
In the present study, the role of the peptidases PepX, PepT, PepO, PepC and PepN in the degradation of model peptides as sources of essential amino acids for L. lactis was examined. This allowed us, for the first time, to determine the substrate specificity of single peptidases of $L$. lactis in vivo and to follow the fate of peptides intracellularly.

\section{Results}

\section{Design of growth experiments}

The $L$. lactis strains (see Table 1 later) were grown in a chemically defined medium (CDM) lacking the essential amino acid Leu, which was supplied in the form of Leucontaining peptides. Growth of a particular mutant was thus fully dependent on the ability of the organism to release Leu from the peptide. When Leu was omitted from CDM (Fig. 1), none of the strains grew, while in a complete amino acid medium, all strains grew equally well. When Leu-Gly was added as a source of Leu, growth was restored to wild-type levels, which was expected because the dipeptidase that hydrolyses this substrate (van Boven et al., 1988) was present in all mutants tested. These control experiments indicate that the mutations per se had no deleterious effect on growth in these media.

\section{Leu-Gly-Gly}

Studies with purified enzymes have shown that Leu-GlyGly can be broken down by a number of peptidases: PepT (Bosman et al., 1990), peptidase 53 (Sahlstrøm et al., 1993), PepN (Tan and Konings, 1990) and PepC (Neviani et al., 1989). When this peptide was used as the only source of Leu, most single- and double-peptidase mutants lacking PepC, PepO, PepN or PepX grew at wild-type rates (Fig. 1). The mutants $[\mathrm{T}]^{-},[\mathrm{XT}]^{-},[\mathrm{XTO}]^{-}$and

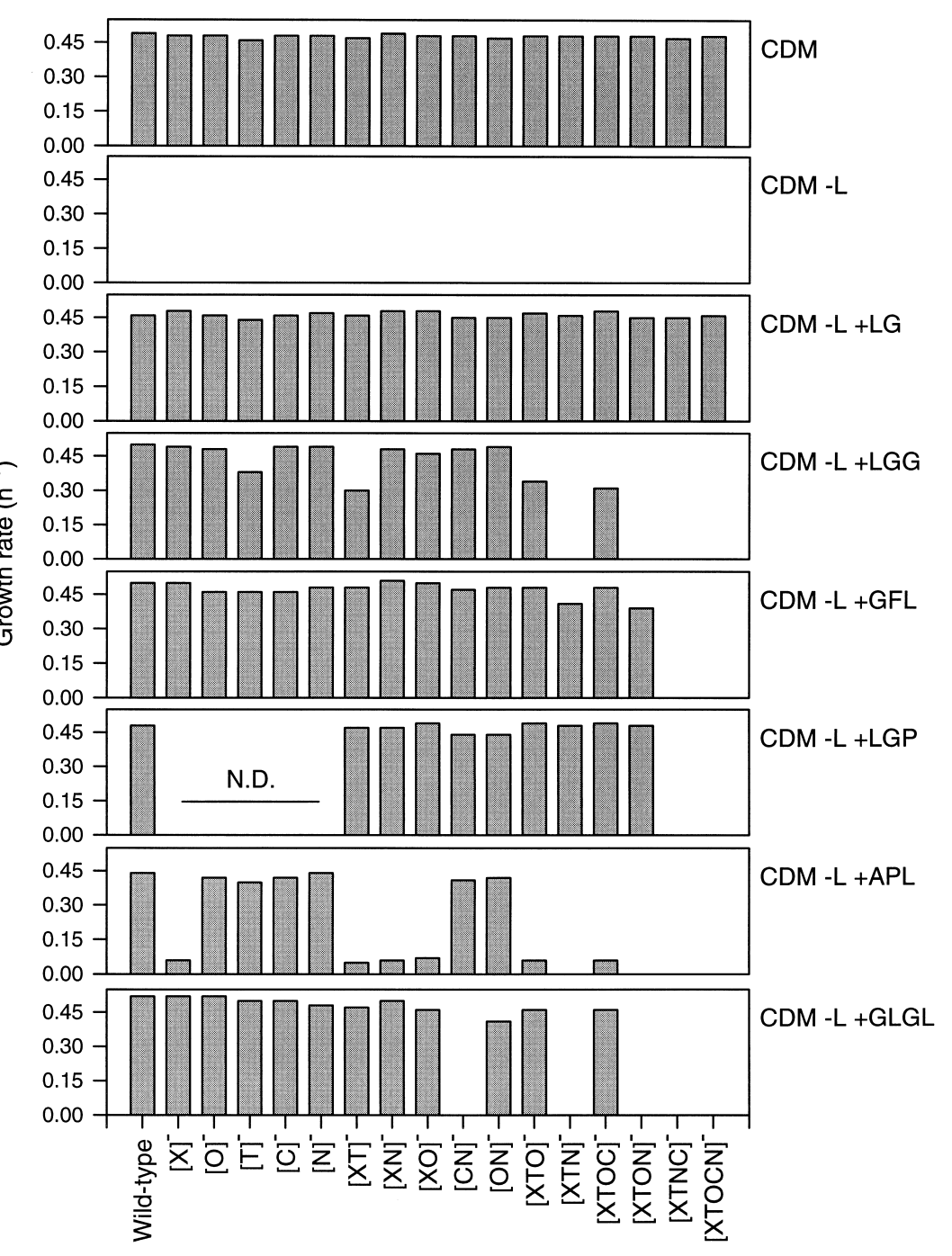

Fig. 1. Growth of peptidase mutants of $L$ lactis on peptides. All strains were grown in chemically defined medium (CDM) containing all amino acids except Glu, Asn, Thr and Cys; in CDM without Leu (CDM -L), and in CDM -L supplemented with Leu-Gly (+LG), Leu-GlyGly (+LGG), Gly-Phe-Leu (+GFL), Leu-GlyPro (+LGP), Ala-Pro-Leu (+APL) or GlyLeu-Gly-Leu (+GLGL) as indicated. N.D., not determined. 
$[\mathrm{XTOC}]^{-}$showed a $25-40 \%$ decrease in growth rate as compared to the wild-type strain, indicating that, in vivo, PepT is involved in breakdown of this peptide. The mutants $[\mathrm{XTN}]^{-}, \mathrm{XTON}^{-},[\mathrm{XTNC}]^{-}$, and $[\mathrm{XTOCN}]^{-}$ did not grow at all on this peptide, indicating that no peptidases other than PepT and PepN are involved in the release of Leu from Leu-Gly-Gly.

\section{Gly-Phe-Leu}

In growth experiments with Gly-Phe-Leu as source of Leu, the $[\mathrm{XTNC}]^{-}$and $[\mathrm{XTOCN}]^{-}$strains were unable to grow, while $[\mathrm{XTN}]^{-}$and $[\mathrm{XTON}]^{-}$had somewhat lower growth rates than the wild-type strain (Fig. 1). Comparison of $[\mathrm{XTN}]^{-}$with $[\mathrm{XTNC}]^{-}$, and $[\mathrm{XTOC}]^{-}$with $[\mathrm{XTOCN}]^{-}$indicates that both $\mathrm{PepC}$ and PepN are involved in the breakdown of Gly-Phe-Leu, respectively. The fact that $[\mathrm{NC}]^{-}$grew at wild-type rates, while $[\mathrm{XTNC}]^{-}$ was unable to grow, points to an involvement of PepT and/ or, less likely, PepX in the hydrolysis of Gly-Phe-Leu.

Leu-Gly-Pro

In CDM supplemented with Leu-Gly-Pro as source of

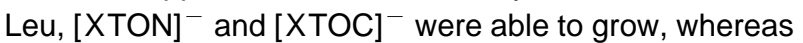
[XTOCN $^{-}$was not. As the fourfold peptidase mutant [XTNC] $^{-}$was also unable to grow, PepN and PepC must be the only enzymes that can release Leu from Leu-GlyPro. Comparison of the growth characteristics of [XTNC] ${ }^{-}$ with those of $[\mathrm{CN}]^{-}$proves the involvement of either PepT or PepX in the degradation of this peptide. In contrast to the breakdown of Gly-Phe-Leu, PepC activity alone was sufficient to release Leu at a rate allowing maximum growth rates.

\section{Ala-Pro-Leu}

The $\mathrm{X}-$ Pro- $Y$ sequence suggests that Ala-Pro-Leu is a substrate of PepX (Booth et al., 1990). The growth experiments clearly showed that Ala-Pro-Leu is broken down by PepX and that this is the only peptidase which allows utilization of this peptide at a rate that sustains maximum growth rates (Fig. 1). Inactivation of PepX alone led to a more than sevenfold decrease of the growth rate. The residual growth seems to be owing to the peptidases PepN and PepT because all mutants lacking PepX, PepT and PepN showed a further decrease in growth rates up to the detection limit.

$$
\text { Gly-Leu-Gly-Leu }
$$

In principle, Gly-Leu-Gly-Leu can be degraded in various ways by PepN, PepC, PepT, PepX, PepO and the dipeptidase. In Fig. 1, two phenotypes can be distinguished. In a number of mutants the growth rates were not significantly affected by the absence of the various peptidases, whereas $[\mathrm{CN}]^{-},[\mathrm{XTN}]^{-},[\mathrm{XTON}]^{-}$, [XTNC] $^{-}$and [XTOCN $^{-}$failed to grow on Gly-LeuGly-Leu. This shows that Gly-Leu-Gly-Leu is broken down efficiently by PepN or by the combination of PepC plus PepT. Strains lacking PepN and PepT, but still containing PepC, did not grow on Leu-Gly-Leu (data not shown), suggesting that PepC cleaved off the first Gly leaving the resulting Leu-Gly-Leu for further degradation by PepT. Neither PepX, PepO nor any other peptidases were apparently involved in the degradation of Gly-LeuGly-Leu.

\section{Tyr-Gly-Gly-Phe-Leu}

Tyr-Gly-Gly-Phe-Met (Met-enkephalin) is degraded by PepN (Tan and Konings, 1990), PepO (Tan et al., 1991) and PepX in vitro (Mayo et al., 1993). The endopeptidases PepF and PepF2 do not digest this peptide (Monnet et al., 1994; M. Nardi and V. Monnet, unpublished). Surprisingly, the $[\mathrm{XTOCN}]^{-}$mutant could still grow on Tyr-Gly-GlyPhe-Leu, while no growth was observed on the tripeptide Leu-Gly-Gly (see above). To exclude the possibility that growth of the $[\mathrm{XTOCN}]^{-}$mutant was the result of impurities of di- or tripeptides in the Tyr-Gly-Gly-Phe-Leu solution, or to extracellular peptide degradation, a strain was used which lacks the oligopeptide-transport system. Indeed, the MG1363(Lopp) mutant strain did not grow on Tyr-Gly-Gly-Phe-Leu, but could use Leu-Gly-Gly because the di-tripeptide transporter DtpT and PepT were present (data not shown).

\section{Fate of peptides in peptidase mutants of $\mathrm{L}$. lactis}

The observation that certain peptidase mutants were unable to utilize peptides in growth experiments prompted us to study the fate of these peptides in peptide-transport assays. When uptake of Leu-Gly-Gly was studied in wildtype cells of $L$. lactis, accumulation of both Gly and Leu was observed, but the tripeptide and derived dipeptides were not detected intracellularly (Fig. 2A). The initial uptake rate of Gly was approximately twice that of Leu, which is in agreement with the ratio of these amino acids in the transported tripeptide Leu-Gly-Gly. Final amino acid accumulation levels were not proportional to the composition of the peptide, as has been observed for other peptides (Tynkkynen et al., 1993; Hagting et al., 1994). When uptake of Leu-Gly-Gly by the $\left[\mathrm{XTOCN}^{-}\right.$mutant was studied, no significant increase in intracellular amino acid concentrations was observed (Fig. 2B). Instead, accumulation of the whole peptide to approx. 25-fold against the concentration gradient was observed (Fig. 2B). This experiment clearly shows that the failure of the 


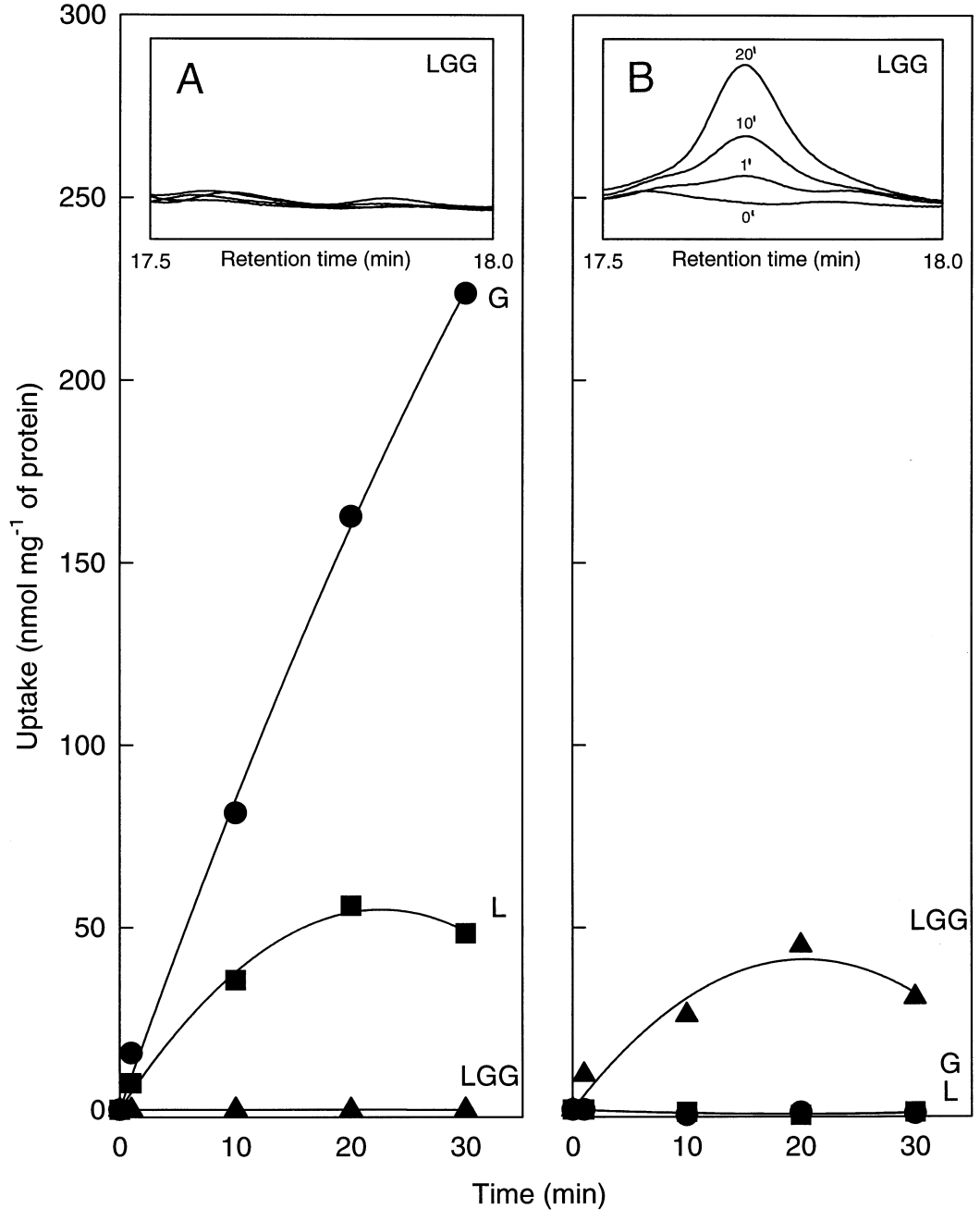

Fig. 2. Uptake of Leu-Gly-Gly (LGG) by wild-type $(A)$ and $[X T O C N]^{-}$mutant $(B)$ cells. Cells were harvested during exponential growth in M17 medium. Prior to the transport assays, cells were de-energized as described in the Experimental procedures. Cells were pre-energized for $3 \mathrm{~min}$ with $0.5 \%(\mathrm{w} / \mathrm{v})$ glucose in $100 \mathrm{mM}$ potassium phosphate, pH6.5, before uptake was started by the addition of $0.5 \mathrm{mM}$ LGG. Peptide and amino acid pools were determined as described in the Experimental procedures. The insets show the high-performance liquid chromatography profiles of intracellular fractions of the wild-type strain (A) and the $[\mathrm{XTOCN}]^{-}$mutant (B) at retention times during which standards of LGG were found to elute. The numbers indicate time-points of LGG uptake.
[XTOCN $]^{-}$mutant to use Leu-Gly-Gly as a source of leucine was because of its inability to degrade this peptide. In contrast, both the wild-type and $\left[\mathrm{XTOCN}^{-}\right.$strains transported Leu-Gly at similar initial rates (4.3 and $4.6 \mathrm{nmol}$ per min per $\mathrm{mg}$ of protein, respectively) and both degraded the peptide fully (data not shown).

Upon addition of Ala-Pro-Leu, accumulation of free Ala, Pro and Leu, but not of the tripeptide, was observed in the wild-type strain (data not shown). The initial uptake rates of Ala, Pro and Leu were similar, indicating that Ala-Pro-Leu was transported prior to degradation. In the $[\mathrm{XTO}]^{-}$mutant, which grew poorly on Ala-Pro-Leu, accumulation of the whole peptide was observed. A small, but significant, increase in the intracellular concentrations of Ala, Pro and Leu was also observed (data not shown) possibly because of the ability of PepN to hydrolyse this peptide slowly.

Both the wild-type and $\left[\mathrm{XTO}^{-}\right.$strains were able to utilize Gly-Leu-Gly-Leu as a source of Leu for growth, while the $[\mathrm{XTOCN}]^{-}$mutant was not. In agreement with these results, the wild-type and $\left[\mathrm{XTO}^{-}\right.$strains hydrolysed the tetrapeptide completely, resulting in approximately equimolar uptake rates of the residues Gly and Leu (Fig. 3, A and B). In contrast, the [XTOCN $]^{-}$strain accumulated the whole peptide intracellularly, while Leu was not increased significantly; some increase in Gly was observed (Fig. 3C). This demonstrates that oligopeptides are also taken up by the cells as whole entities. The small increase in free Gly is probably not the result of degradation of Gly-Leu-Gly-Leu, because neither Leu nor Leu-Gly-Leu pools were observed to increase (data not shown). A small and variable increase in Gly pools has previously been noticed in glycolysing cells of L. lactis resulting from the synthesis from precursors of the glycolytic pathway (see also Kunji et al., 1995). Comparison of the $\left[\mathrm{XTO}^{-}\right.$and $[\mathrm{XTOCN}]^{-}$mutants shows that GlyLeu-Gly-Leu is degraded by PepN and PepC, confirming the results of the growth experiments.

The growth experiments showed that the $[\mathrm{XTOCN}]^{-}$ mutant could still utilize Tyr-Gly-Gly-Phe-Leu. Analysis 

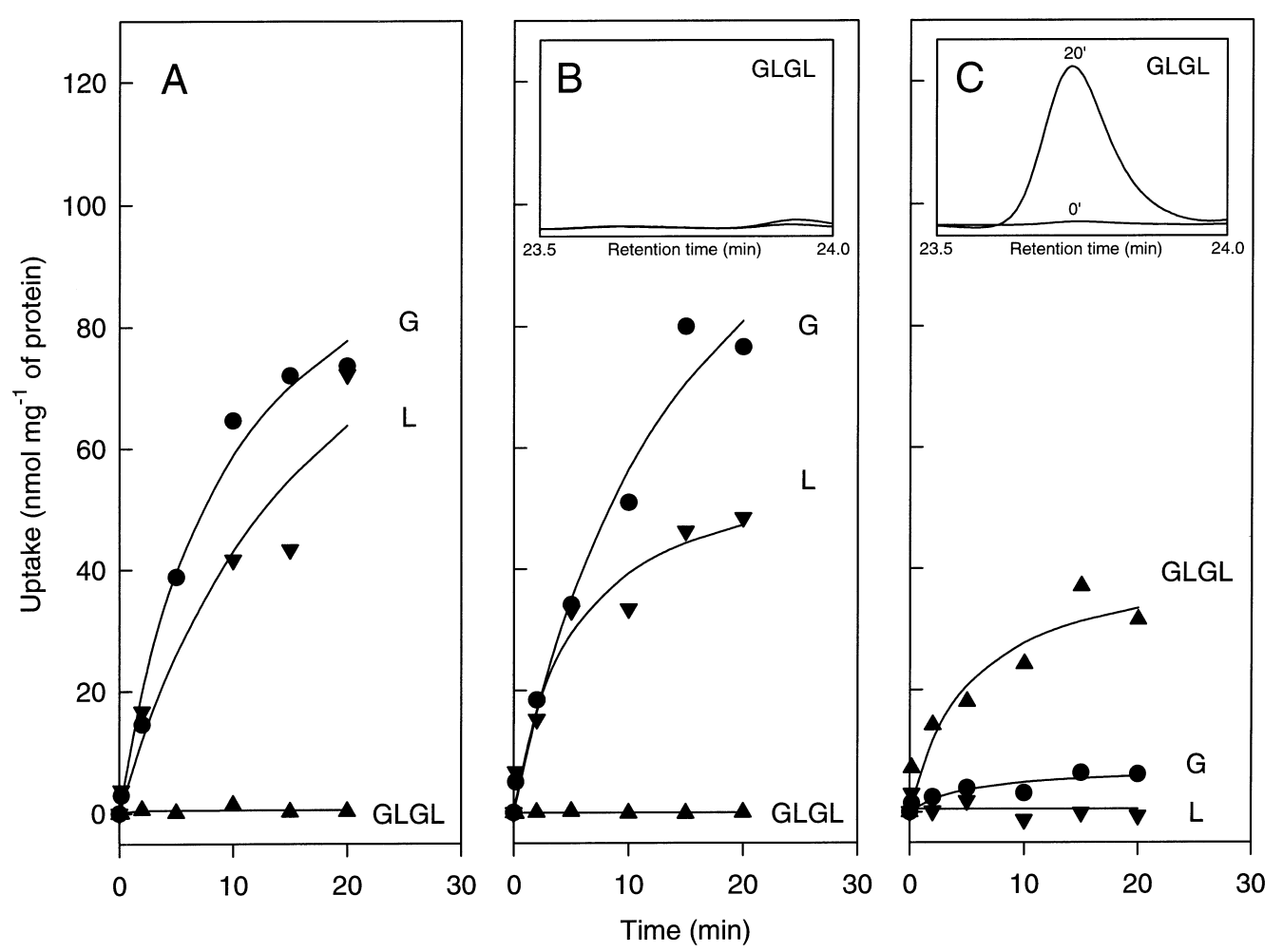

Fig. 3. Uptake of Gly-Leu-Gly-Leu (GLGL) by wild-type (A), $[X T O]^{-}$(B) and $[X T O C N]^{-}(C)$ strains. The transport experiments were performed as described in the legend to Fig. 2. Uptake was started by the addition of $0.5 \mathrm{mM}$ GLGL to glucose-energized cells. The insets show the HPLC analysis of intracellular fractions of the $[X T O]^{-}$(B) and the $[X T O C N]^{-}$(C) mutant at retention times during which standards of GLGL were found to elute. The numbers indicate the time-points of GLGL uptake.

of the intracellular breakdown products of this peptide in the wild-type strain and the $\left[\mathrm{XTO}^{-}\right.$and $[\mathrm{XTOCN}]^{-}$ mutants showed that Tyr, Gly, Phe and Leu accumulated in the wild-type and in the [XTO] ${ }^{-}$mutant, whereas the pentapeptide, or its possible derived fragments, did not (Fig. 4, A and B). Gly accumulated with approximately twice the initial rate of that of the other residues, which is in agreement with the molar composition of the peptide. In contrast, the peptidase activity in the $[\mathrm{XTOCN}]^{-}$mutant released Phe and Leu, but not Tyr and Gly. Instead, the tripeptide Tyr-Gly-Gly accumulated with an initial rate similar to that of Phe and Leu. These data substantiate the conclusions drawn from the growth experiments by showing directly that the $[\mathrm{XTOCN}]^{-}$mutant is able to release Leu from Tyr-Gly-Gly-Phe-Leu.

\section{Discussion}

In this study, single peptides containing the essential amino acid Leu were offered to well-characterized peptidase mutants, and growth in a chemically defined medium as well as degradation of the peptide were monitored. Using this approach, several features of exogenous peptide metabolism in L. lactis were unravelled.

First, PepN, PepC, PepX and PepT are, in vivo, responsible for the release of amino acids from the triand tetrapeptides tested, while PepO does not act on these substrates. In those peptidase mutants in which growth was abolished, intracellular accumulation of whole peptides was observed, confirming the notion that remaining peptidase activities are unable to degrade these peptides. One surprising observation was that $P e p C$ alone is sufficient to allow $L$. lactis to grow on Leu-Gly-Pro as the sole source of Leu, but not on LeuGly-Gly. Biochemical analyses have shown that LeuGly-Gly can be broken down by PepC at activities that are comparable to those for other peptides (Neviani et al., 1989). Apparently, data obtained from in vitro studies cannot always be extrapolated to the in vivo situation. Because the growth defect is complete in mutants lacking PepT and PepN, it must be concluded that no other peptidases are present that can efficiently hydrolyse Leu-Gly-Gly.

Second, peptidases were identified which have overlapping specificities in vivo. This is true for the degradation of Gly-Phe-Leu and Leu-Gly-Pro by the general aminopeptidases PepN, PepC and PepT and for the degradation of Leu-Gly-Gly by PepT and PepN. Growth on these peptides was only abolished when mutations of the corresponding peptidases were combined. Although PepN 


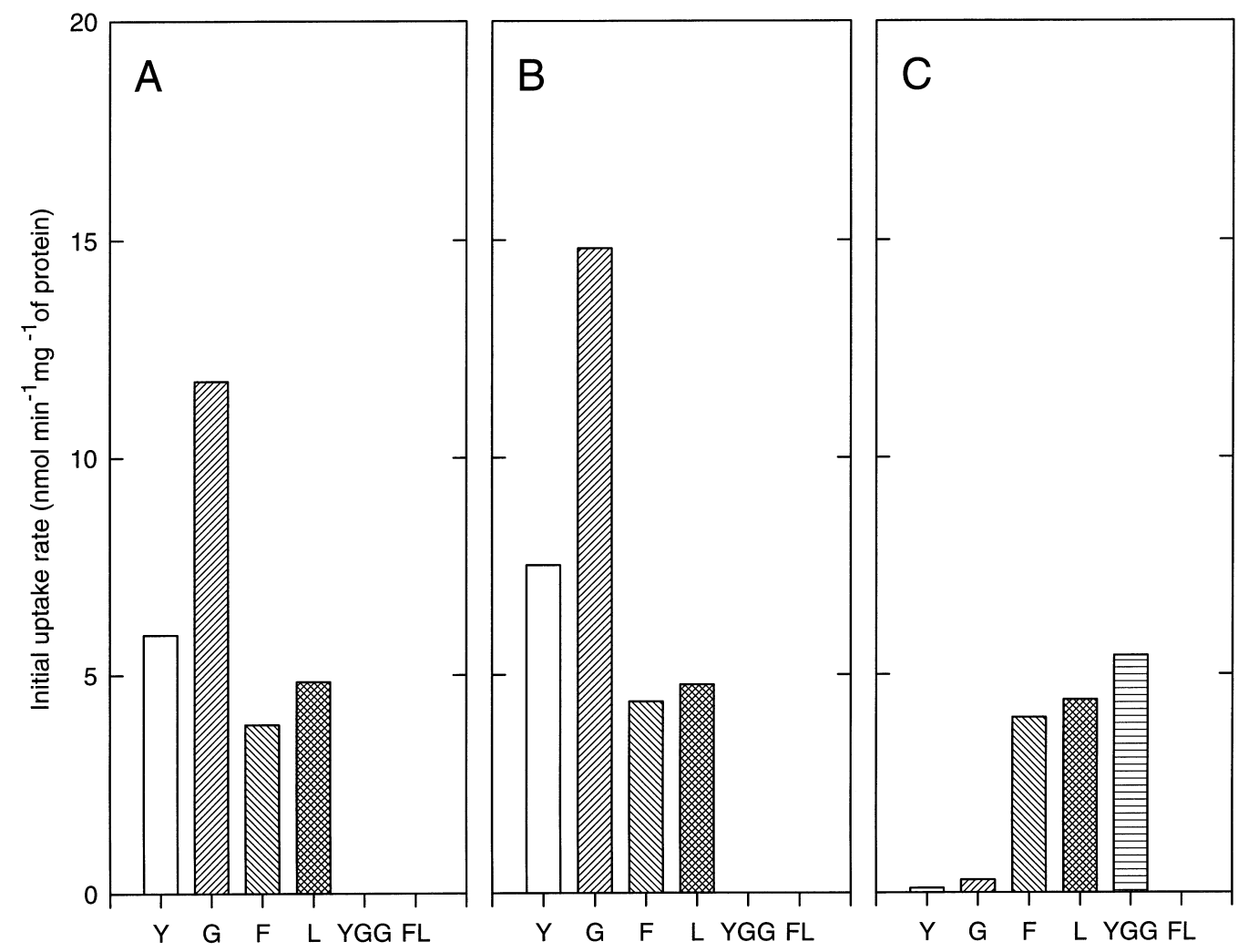

Fig. 4. Initial rates of Tyr-Gly-Gly-Phe-Leu (YGGFL) uptake by wild-type (A), $[X T O]^{-}(B)$ and $[X T O C N]^{-}$(C) strains. The transport experiments were performed as described in the legend to Fig. 2. Uptake was started by the addition of $0.5 \mathrm{mM}$ Tyr-Gly-Gly-Phe-Leu to glucose-energized cells. The initial rates were calculated as the derivative at time-point zero of a second-order polynome fitted to the uptake curves of the hydrolysis products of Tyr-Gly-Gly-Phe-Leu.

can replace PepT in the degradation of Leu-Gly-Gly, the 'overall rate' (defined as $[E] \cdot T N \cdot K_{m}^{-1}$, in which $[E]$ is the enzyme concentration, TN is the turnover number of the enzyme and $K_{\mathrm{m}}$ is the affinity constant for the substrate) of PepN is lower than that of PepT because strains lacking PepT, but containing PepN, grow at a reduced rate compared to strains containing PepT, but lacking PepN. Similar observations were made for the degradation of Gly-Phe-Leu by PepN and PepC compared to PepN, respectively, and of Ala-Pro-Leu by PepN and PepT compared to PepX, respectively. Overlapping substrate specificities have also been observed in peptidase mutants of $E$. coli and $S$. typhimurium (Miller and Schwartz, 1978; Miller and Mackinnon, 1974).

Third, L. lactis MG1363 contains peptidases with unique specificities, in addition to peptidases with general and overlapping specificities. PepX, for instance, is the only peptidase that has major activity to degrade the tripeptide Ala-Pro-Leu. No other peptidase or combination of peptidases could fully take over its function. PepN and PepT have very low overall degradation rates towards Ala-Pro-Leu, allowing only limited growth.

Fourth, concerted action of peptidases in the breakdown of peptides was observed. For instance, in the absence of PepN, Gly-Leu-Gly-Leu could only be degraded by the co-operative action of two peptidases, i.e. PepC and PepT. PepC removes the first Gly, but is unable to degrade the product Leu-Gly-Leu. PepT, which cannot hydrolyse tetrapeptides, subsequently liberates Leu from the tripeptide.

Fifth, analysis of intracellular fractions has given information about the presence or absence of alternative degradation pathways. Some mutants are unable to degrade the peptides under study, indicating that these mutants contain no other peptidases that have measurable overall rates of hydrolysis for these peptides. The fivefold mutant $[\mathrm{XTOCN}]^{-}$can still release Leu from TyrGly-Gly-Phe-Leu; because the tripeptide Tyr-Gly-Gly was detected in these cells, the pentapeptide must be hydrolysed after the second Gly. The released Phe-Leu can be hydrolysed by the dipeptidase, which is still present in the $[\mathrm{XTOCN}]^{-}$mutant. An additional PepO-like activity is probably responsible for the degradation of Tyr-GlyGly-Phe-Leu. Indeed, in pepO mutants, degradation of this peptide is decreased by $50 \%$, and only after addition of the inhibitor phenanthroline is endopeptidase activity 
completely blocked (A. Beaumont, unpublished). Moreover, Southern hybridization analysis with a pepOspecific DNA probe has revealed the presence of another PepO-like endopeptidase gene on the chromosome (M. A. Hellendoorn and I. Mierau, unpublished).

Sixth, the use of mutants that were unable to degrade certain peptides allowed us, for the first time, to observe accumulation of whole tri- and tetrapeptides in cells of L. lactis. Combined with the fact that peptide-transport mutants are completely impaired in their ability to accumulate amino acid residues from extracellular peptides (Tynkkynen et al., 1993; Hagting et al., 1994), it is clear that transport of peptides occurs prior to their intracellular hydrolysis. So far, accumulation of whole peptides in vivo has only been shown for Gly-Gly in E. coli cells lacking dipeptidase activity (Kessel and Lubin, 1963). Degradation of peptides in wild-type cells seriously hampers kinetic analysis of peptide transport in whole cells. The observed accumulation of amino acids in the wild-type strain is the result of peptide transport, degradation, amino acid metabolism and efflux. By eliminating peptidase activity, it is now possible to study kinetic aspects of peptide transport in intact cells, such as product inhibition and substrate competition.

The proteolytic system of $L$. lactis has become one of the best-defined and -characterized pathways for the degradation of exogenous proteins (caseins). The availability of other peptidase genes and the elegant tools to inactivate them make it possible to address the role of the complete spectrum of lactococcal peptidases in proteolysis. In future experiments, multiple peptidase mutants will also be used to analyse the kinetic properties of peptide transport in vivo. The casein-derived peptides that are transported into the lactococcal cell will be identified and their breakdown routes will be reconstructed.

\section{Experimental procedures}

\section{Strains and media}

The strains used in this study are listed in Table 1 . The strains were grown and maintained in M17 medium (Terzaghi and Sandine, 1975) with $0.5 \%$ glucose (GM17) at $30^{\circ} \mathrm{C}$ as standing cultures. CDM was prepared according to Rogosa et al. (1961) with modifications: in $90 \mathrm{ml}$ water were dissolved $29 \mathrm{mg}$ tyrosine (in boiling MilliQ water), $2.1 \mathrm{~g} \mathrm{Na}-\beta$-glycerophosphate, $0.1 \mathrm{~g} \mathrm{KH}_{2} \mathrm{PO}_{4}, 60 \mathrm{mg}\left(\mathrm{NH}_{4}\right)_{3}$ citrate and $0.1 \mathrm{~g}$ $\mathrm{Na}$-acetate (Exterkate and de Veer, 1987). Subsequently, $1 \mathrm{ml}$ vitamin mix (Jensen and Hammer, 1993), $1 \mathrm{ml}$ metal mix (Jensen and Hammer, 1993), $5 \mathrm{ml}$ amino acid mix (Poolman and Konings, 1988), $0.1 \mathrm{ml}$ of a $\mathrm{MnCl}_{2}$ solution in water $\left(28 \mathrm{mg} \mathrm{m}^{-1}\right), 25 \mathrm{mg}$ cysteine (optional) and $0.5 \%$ glucose were added. The $\mathrm{pH}$ was adjusted to 6.4 and the medium was sterilized by filtration. For the growth experiments with leucine-containing peptides, leucine was omitted from the amino acid mix. All peptides were used at a concentration of
Table 1. L. lactis strains used in this work.

\begin{tabular}{|c|c|c|c|}
\hline $\begin{array}{l}\text { L. lactis subsp. } \\
\text { cremoris strain }\end{array}$ & $\begin{array}{l}\text { Relevant } \\
\text { characteristics }\end{array}$ & $\mathrm{Name}^{\mathrm{a}}$ & Reference \\
\hline MG1363 & $\begin{array}{l}\text { Plasmid-free } \\
\text { derivative of } \\
\text { NCDO712 }\end{array}$ & Wild type & Gasson (1983) \\
\hline GL291 & MG1363 $\Delta p e p X$ & {$[\mathrm{X}]^{-}$} & $\begin{array}{l}\text { K. J. Leenhouts } \\
\quad \text { et al. } \\
\text { (submitted) }\end{array}$ \\
\hline IM2 & MG1363 $\Delta p e p O$ & {$[\mathrm{O}]^{-}$} & $\begin{array}{l}\text { Mierau et al. } \\
\quad(1996)\end{array}$ \\
\hline IM3 & MG1363 $\Delta p e p T$ & {$[\mathrm{~T}]^{-}$} & $\begin{array}{l}\text { Mierau et al. } \\
\quad(1994)\end{array}$ \\
\hline IM4 & MG1363 $\Delta p e p C$ & {$[\mathrm{C}]^{-}$} & $\begin{array}{l}\text { Mierau et al. } \\
(1996)\end{array}$ \\
\hline IM5 & MG1363 $\Delta p e p N$ & {$[N]^{-}$} & $\begin{array}{l}\text { Mierau et al. } \\
\text { (1996) }\end{array}$ \\
\hline IM6 & $\begin{array}{l}\text { MG1363 } \Delta p e p X \\
\quad \Delta p e p T\end{array}$ & {$[X T]^{-}$} & $\begin{array}{l}\text { Mierau et al. } \\
(1996)\end{array}$ \\
\hline IM7 & $\begin{array}{l}\text { MG1363 } \Delta p e p X \\
\quad \Delta p e p N\end{array}$ & {$[\mathrm{XN}]^{-}$} & $\begin{array}{l}\text { Mierau et al. } \\
(1996)\end{array}$ \\
\hline IM8 & $\begin{array}{l}\text { MG1363 } \Delta \text { pepX } \\
\quad \Delta p e p O\end{array}$ & {$[\mathrm{XO}]^{-}$} & $\begin{array}{l}\text { Mierau et al. } \\
(1996)\end{array}$ \\
\hline IM9 & $\begin{array}{l}\text { MG1363 } \Delta p e p C \\
\quad \Delta p e p N\end{array}$ & {$[\mathrm{CN}]^{-}$} & $\begin{array}{l}\text { Mierau et al. } \\
\text { (1996) }\end{array}$ \\
\hline IM10 & $\begin{array}{l}\text { MG1363 } \Delta \text { pepO } \\
\quad \Delta p e p N\end{array}$ & {$[\mathrm{ON}]^{-}$} & $\begin{array}{l}\text { Mierau et al. } \\
(1996)\end{array}$ \\
\hline IM11 & $\begin{array}{l}\text { MG1363 } \Delta \text { pepX } \\
\quad \Delta p e p T \\
\quad \Delta \text { pepO }\end{array}$ & {$[\mathrm{XTO}]^{-}$} & $\begin{array}{l}\text { Mierau et al. } \\
\quad(1996)\end{array}$ \\
\hline IM12 & $\begin{array}{l}\text { MG1363 } \Delta p e p X \\
\quad \Delta p e p T \\
\quad \Delta p e p N\end{array}$ & {$[\mathrm{XTN}]^{-}$} & $\begin{array}{l}\text { Mierau et al. } \\
\quad(1996)\end{array}$ \\
\hline IM13 & $\begin{array}{l}\text { MG1363 } \Delta \text { pepX } \\
\quad \Delta p e p T \\
\quad \Delta p e p O \\
\Delta p e p C\end{array}$ & {$\left[\mathrm{XTOC}^{-}\right.$} & $\begin{array}{l}\text { Mierau et al. } \\
\text { (1996) }\end{array}$ \\
\hline IM14 & $\begin{array}{l}\text { MG1363 } \Delta \text { pepX } \\
\quad \Delta p e p T \\
\quad \Delta p e p O \\
\Delta p e p N\end{array}$ & {$[\mathrm{XTON}]^{-}$} & $\begin{array}{l}\text { Mierau et al. } \\
\quad(1996)\end{array}$ \\
\hline IM15 & $\begin{array}{l}\text { MG1363 } \Delta \text { pepX } \\
\quad \Delta p e p T \\
\Delta p e p N \\
\Delta p e p C\end{array}$ & {$[\mathrm{XTNC}]^{-}$} & $\begin{array}{l}\text { Mierau et al. } \\
\text { (1996) }\end{array}$ \\
\hline IM16 & $\begin{array}{l}\text { MG1363 } \Delta \text { pepX } \\
\quad \Delta \text { pepT } \\
\Delta \text { pepO } \\
\Delta \text { pepC } \\
\Delta \text { pepN }\end{array}$ & {$[\mathrm{XTOCN}]^{-}$} & $\begin{array}{l}\text { Mierau et al. } \\
\quad(1996)\end{array}$ \\
\hline IM17 & $\begin{array}{l}\text { MG1363 } \\
\quad \Delta o p p, \Delta \text { pepO }\end{array}$ & $\mathrm{Opp}^{-}$ & $\begin{array}{l}\text { I. Mierau } \\
\text { unpublished }\end{array}$ \\
\hline
\end{tabular}

a. The name by which these strains, for convenience, are referred to in this article.

$400 \mu \mathrm{M}$. The growth experiments in CDM were conducted as follows: $1 \mathrm{ml}$ of an overnight culture in GM17 was washed twice with $0.9 \% \mathrm{NaCl}$ solution and inoculated at $1 \%$ (v/v) into CDM. Subsequently, $250 \mu$ of the culture was transferred into a well of a microtitre plate (Greiner $\mathrm{GmbH}$ ) and covered with $50 \mu \mathrm{l}$ of silicone oil $\left(1.01 \mathrm{~g} \mathrm{ml}^{-1}\right.$; WackerChemie $\mathrm{GmbH}$ ) in order to apply semi-anaerobic conditions and to prevent evaporation. Growth was monitored at $595 \mathrm{~nm}$ in the THERMOmax kinetic microtiterplate reader (Molecular Devices Corporation). Each growth experiment 
was carried out in duplicate and on different days. Growth rates were estimated from logarithmic equations fitted to data points taken during exponential growth.

\section{Peptide-transport assays}

Wild-type and mutant strains were grown in GM17 and harvested during late exponential growth. Subsequently, cells were washed with $100 \mathrm{mM}$ potassium phosphate, $\mathrm{pH} 6.5$, and concentrated to an $\mathrm{OD}_{660}$ of approximately 25 . To inhibit protein synthesis, chloramphenicol $\left(50 \mu \mathrm{g} \mathrm{ml}^{-1}\right)$ was present in all buffers during further steps. To release amino acids, cells were de-energized with $10 \mathrm{mM}$ 2-deoxyglucose for $20 \mathrm{~min}$ at $30^{\circ} \mathrm{C}$, washed again twice with $100 \mathrm{mM}$ potassium phosphate, $\mathrm{pH} 6.5$, and resuspended in the same buffer. For transport assays, cells $\left(\mathrm{OD}_{660}\right.$ approx. 15) were pre-incubated for $3 \mathrm{~min}$ in the presence of $25 \mathrm{mM}$ glucose, after which $0.5 \mathrm{mM}$ of peptide was added. Transport was monitored by determining the intracellular amino acid and peptide pools at various time intervals as described (Kunji et al., 1993; Mierau et al., 1996). Differences in efficiency of dansylation of peptides and amino acids were corrected by calibrating with the appropriate standards at different concentrations.

\section{Chemicals}

All peptides were obtained from Bachem Feinchemikalien AG: Leu-Gly, Leu-Gly-Gly, Leu-Gly-Pro, Ala-Pro-Leu, Gly-Phe-Leu, Gly-Leu-Gly-Leu, Leu-Gly-Leu, and TyrGly-Gly-Phe-Leu and the amino acids were all in the L-configuration. MilliQ water was used throughout all experiments.

\section{Acknowledgements}

The research of E.K. and I.M. was supported by the BRIDGE T Project of the Biotechnology Programme of the European Community. J.K. is the recipient of a fellowship of the Royal Netherlands Academy of Arts and Sciences (KNAW)

\section{References}

Booth, M., Fhaoláin, I.N., Jennings, P.V., and O'Cuinn, G. (1990) Purification and characterization of a post-proline dipeptidyl aminopeptidase from Streptococcus cremoris AM2. J Dairy Res 57: 89-99.

Bosman, B.W., Tan, P.S.T., and Konings, W.N. (1990) Purification and characterization of a tripeptidase from Lactococcus lactis subsp. cremoris Wg2. Appl Environ Microbiol 56: 1839-1843.

van Boven, A., Tan, P.S.T., and Konings, W.N. (1988) Purification and characterization of a dipeptidase from Streptococcus cremoris Wg2. Appl Environ Microbiol 54: 43-49.

Exterkate, F.A., and de Veer, G.J.C.M. (1987) Optimal growth of Streptococcus cremoris HP in milk is related to $\beta$ - and $\kappa$-casein degradation. Appl Microbiol Biotechnol 25: 471-475.

Gasson, M.J. (1983) Plasmid complements of Streptococcus lactis NCDO712 and other lactic streptococci after protoplast-induced curing. J Bacteriol 154: 1-9.

Hagting, A., Kunji, E.R.S., Leenhouts, K.J., Poolman, B., and Konings, W.N. (1994) The di- and tripeptide transport protein of Lactococcus lactis; a new type of bacterial peptide transporter. J Biol Chem 269: 11391-11399.

Jensen, P.R., and Hammer, K. (1993). Minimal requirements for exponential growth of Lactococcus lactis. Appl Environ Microbiol 59: 4363-4366.

Juillard, V., Laan, H., Kunji, E.R.S., Jeronimus-Stratingh, C.M., Bruins, A.P., and Konings, W.N. (1995) The extracellular $\mathrm{P}_{\mathrm{I}}$-type proteinase of Lactococcus lactis hydrolyzes $\beta$-casein into more than one hundred different oligopeptides. J Bacteriol 177: 3472-3478.

Kessel, D., and Lubin, M. (1963) On the distinction between peptidase activity and peptide transport. Biochim Biophys Acta 71: 656-663.

Kunji, E.R.S., Smid, E.J., Plapp, R., Poolman, B., and Konings, W.N. (1993) Di- and tripeptides and oligopeptides are transported via distinct transport mechanisms in Lactococcus lactis. J Bacteriol 175: 2052-2059.

Kunji, E.R.S., Hagting, A., de Vries, C.J., Juillard, V., Haandrikman, A.J., Poolman, B., and Konings, W.N. (1995) Transport of $\beta$-casein-derived peptides by the oligopeptide transport system is a crucial step in the proteolytic pathway of Lactococcus lactis. $J$ Biol Chem 270: 1569-1574.

Kunji, E.R.S., Mierau, I., Hagting, A., Poolman, B., and Konings, W.N. (1996) The proteolytic systems of lactic acid bacteria. Antonie van Leeuwenhoek, in press.

Mayo, B., Kok, J., Bockelmann, W., Haandrikman, A., Leenhouts, K.J., and Venema, G. (1993) Effect of Xprolyl dipeptidyl aminopeptidase deficiency on Lactococcus lactis. Appl Environ Microbiol 59: 2049-2055.

Mierau, I., Haandrikman, A.J., Velterop, O., Tan, P.S.T., Leenhouts, K.L., Konings, W.N., Venema, G., and Kok, J. (1994) Tripeptidases gene (pepT) of Lactococcus lactis: Molecular cloning and nucleotide sequencing of pepT and construction of a chromosomal deletion mutant. $J$ Bacteriol 176: 2854-2861.

Mierau, I., Kunji, E.R.S., Leenhouts, K.J., Hellendoorn, M., Haandrikman, A.J., Poolman, B., Konings, W.N., Venema, G., and Kok, J. (1996) Multiple peptidase mutants of Lactococcus lactis are severely impaired in their ability to grow in milk. J Bacteriol 178: 2794-2803.

Miller, C.G., and Green, L. (1983) Degradation of proline peptides in peptidase-deficient strains of Salmonella typhimurium. J Bacteriol 153: 350-356.

Miller, C.G., and Mackinnon, K. (1974) Peptidase mutants of Salmonella typhimurium. J Bacteriol 120: 355-363.

Miller, C.G., and Schwartz, G. (1978) Peptidase-deficient mutants of Escherichia coli. J Bacteriol 135: 603-611.

Monnet, V., Nardi, M., Chopin, A., Chopin, M.-C., and Gripon, J.-C. (1994) Biochemical and genetic characterization of PepF, an oligopeptidase from Lactococcus lactis. J Biol Chem 269: 32070-32076.

Neviani, E., Boquien, C.Y., Monnet, V., Phan Thanh, L., and Gripon, J.-C. (1989) Purification and characterization of an aminopeptidase from Lactococcus lactis subsp. cremoris AM2. Appl Environ Microbiol 55: 2308-2314.

Payne, J.W., and Smith, M.W. (1994) Peptide transport by 
micro-organisms. In Advances in Microbial Physiology. Vol. 6. Rose, A.H., and Tempest, D.W. (eds). London: Academic Press, pp. 2-80.

Poolman, B., and Konings, W.N. (1988) Relation of growth of Streptococcus lactis and Streptococcus cremoris to amino acid transport. J Bacteriol 170: 700-707.

Rogosa, M., Franklin, J.G., and Perry, K.D. (1961). Correlation of the vitamin requirements with cultural and biochemical characters of Lactobacillus spp. J Gen Microbiol 25: 473-482.

Sahlstrøm, S., Chrzanowska, J., and Sørhaug, T. (1993) Purification and characterization of a cell wall peptidase from Lactococcus lactis subsp. cremoris IMN-C12. Appl Environ Microbiol 59: 3076-3082.

Tan, P.S.T., and Konings, W.N. (1990) Purification and characterization of an aminopeptidase from Lactococcus lactis subsp. cremoris Wg2. Appl Environ Microbiol 56: 526-532.
Tan, P.S.T., Pos, K.M., and Konings, W.N. (1991) Purification and characterization of an endopeptidase from Lactococcus lactis subsp. cremoris Wg2. Appl Environ Microbiol 57: 3593-3599.

Terzaghi, B.E., and Sandine, W.E. (1975) Improved medium for lactic streptococci and their bacteriophages. Appl Microbiol 29: 807-813.

Tynkkynen, S., Buist, G., Kunji, E., Kok, J., Poolman, B., Venema, G., and Haandrikman, A.J. (1993) Genetic and biochemical characterization of the oligopeptide transport system of Lactococcus lactis. J Bacteriol 175: 75237532.

Yen, C., Green, L., and Miller, C.G. (1980a) Degradation of intracellular protein in Salmonella typhimurium peptidase mutants. J Mol Biol 143: 21-33.

Yen, C., Green, L., and Miller, C.G. (1980b) Peptide accumulation during growth of peptidase deficient mutants. $J \mathrm{Mol}$ Biol 143: 35-48. 